\title{
Eastern European Revolutionary Movements
}

By the time World War I broke out, various political organisations existed in the smaller Eastern European polities and the minority regions, but nowhere had a well-organised revolutionary party emerged in the countryside, as such parties did prior to a number of anti-colonial revolutions. Certainly none of these smaller polities or nationally distinct regions was predestined to social revolution in the following years. But revolutions did occur in some of them between 1917 and 1919, and in nearly all other cases such a conflict seemed possible at one time or another.

In order to determine the factors that account for these challenges, all of the smaller Eastern European polities should, at least in principle, be taken into account. In this chapter, the nature of the conflicts will be discussed in terms of the three-part perspective utilised above: (agrarian) class relations, political dependence, and organised challengers as expressions of national and class integration.

Nearly everywhere a subordinate position in the capitalist world-economy and increased demographic pressure had transformed traditional agrarian class relations and created an incipient industrial proletariat. In some cases local upper classes were closely tied to the metropole culturally or economically; in other cases the ties were looser. Regions also varied markedly in the character of political dependence. A notable transition occurred, of course, in the Ottoman Empire, which was forced to abandon its control by 1914 . Moreover, the degree of local autonomy varied considerably within each empire as well. These two conditions shaped the third factor, the character of popular political organisation before the world war.

As in the case of Finland, a fourth, short-term condition should be added: the mode and timing of the collapse of the mother empire, combined with the direct pressure of war on the local structures of power. The three long-term factors determined the nature of the challenge on the eve of the final breakdown of the metropole, whereas the long- and short-term factors together affected both the ability of the challengers to mobilise the masses after 1917 and the way the existing local authority disintegrated.

This perspective makes it easier to identify the major differences between the European cases and the majority of the colonial cases and to situate Finland among the Eastern European dependent nationalities.

Between 1830 and 1918, twelve nationally distinct independent states emerged in Eastern Europe as Russia, Austria-Hungary, and the Ottoman

(C) KONINKLIJKE BRILL NV, LEIDEN, 2019 | DOI:10.1163/9789004386174_012

This is an open access chapter distributed under the terms of the CC BY-NC-ND $4_{R} 0$ license lapuro $_{\text {- }} 9789004386174$ 
Empire disintegrated: Finland (1917), Estonia (1918), Latvia (1918), Lithuania (1918), Poland (1918), Czechoslovakia (1918), Hungary (1918), Romania (1878), Bulgaria (1908), Yugoslavia (1918), Albania (1913), and Greece (1830). All these cases cannot be examined here, not even all the so-called successor states, created or re-created at the end of the war. Presumably the most relevant cases for comparison are two other cases of autonomist nationalism in the Russian Empire:1 the neighbouring Baltic Provinces, soon to be Estonia and Latvia. The rudimentary polities of these regions, too, were directly affected by the revolution of 1905 as well as by the February and October revolutions.

In the Habsburg Empire dismemberment brought about a revolution in Hungary ${ }^{2}$ and, together with substantial help from the labour movement, the birth of the Czechoslovak state. In the Balkans the war eliminated the vestiges of the Ottoman period and led to a major territorial expansion in Romania, a kind of peasant revolution in Bulgaria, and the expansion of Serbia in the new state of Yugoslavia. Yet no outright social revolution occurred in the Balkans, despite some critical moments. The same holds for Poland, which had been divided among three empires.

Finally, inter-war fascism in Eastern Europe bears strong marks of local social structures, of problems created by the reformation of political systems after World War I, and of the memories of revolutionary unrest in 1917-20. The rapid re-establishment of traditional elites and economic dependence on the more developed countries of Western Europe appear to be key factors influencing the Eastern variant of fascism.

Three conditions that paved the way for the steady advancement of Finnish nationalism were mentioned in Chapter 5. First, Finland was an established, separate political unit, whose distinctiveness was consolidated in the course of the nineteenth century. Second, its upper classes had adopted neither the native Finnish nor the metropolitan Russian culture but rather the Swedish language and culture; therefore, external political domination on the one hand

1 Orridge and Williams 1982, p. 21. Despite a revolutionary situation in 1918-19, I decided to omit the other Baltic territories, or the Lithuanian-speaking areas, from this discussion because they were occupied by the Germans in $1915^{-18}$. Besides, they did not have a separate political structure even to the degree the Baltic Provinces had.

2 No other revolutionary situations occurred elsewhere in East-Central Europe, except the short-lived Slovak Socialist Republic created by the Hungarian revolution. 
and internal cultural and economic domination on the other were not superimposed on one another. Third, because a non-feudal class structure with a large, strong indigenous peasantry had been consolidated during the Swedish period, the dominant position of Finland's upper classes was not based primarily on landownership. Baltic deviations from this pattern seem to explain many of the differences between the Estonian and Latvian national movements and the Finnish movement. In the former, the first and third conditions were not fulfilled; only the second one was. But because the three conditions interacted, even this seeming similarity had different consequences in the two cases.

In the three Baltic Provinces of Estland, Livland, and Kurland, populated by Estonians and Latvians (see Map 10), ${ }^{3}$ noble landownership was the most extensive, and capitalist development in agriculture the most intensive, in all of European Russia. At the beginning of the twentieth century the average size of estates in the gubernii of Estland and Livland was 2,677 and 3,232 desiatinas (one desiatina being the equivalent of 2.7 acres), respectively, whereas the corresponding figure for European Russia as a whole was 496 desiatinas. ${ }^{4}$ Although members of the estate-owning German nobility were less than one percent of the agrarian population, they owned about half the available land. ${ }^{5}$ To keep the labour force in place large tracts were leased to the peasantry, especially after internal passport reforms in the 186os made it easy for peasants to migrate to the cities and to the Russian interior. Money rent predominated, but labour rent and other feudal obligations survived until the early 190os. ${ }^{6}$

Besides tenant farmers and cottagers, the huge estates needed many agrarian wageworkers. These workers constituted one-quarter of the local labour force, by far the largest proportion of any workforce in European Russia. ${ }^{7}$ Thus in the Baltic Provinces the so-called Prussian way to capitalism in agriculture had progressed further than anywhere else in the empire. On one side there was a conservative capitalist Junker-type class, on the other a growing class of agrarian wageworkers. Commercialisation, however, occurred more slowly

3 Lettgallia was also a Latvian-speaking region, but the elites were Russian and Polish and the villages were closer to the Russian type than were those in the Baltic Provinces.

4 Istoriia Estonskoi SSR 1966, 351-2.

5 In the Estonian-speaking areas, estate owners and their family members accounted for 0.7 percent of the total agrarian population in 1916 (Siilivask 1975, p. 69); according to Koval'chenko and Borodkin (1979, p. 87), noble lands accounted for 49 percent of total lands at the turn of the century. Local Estonian and Latvian historians give somewhat higher percentages, often including state and church properties (Saat and Siilivask 1977, p. 27; Istoriia Estonskoi SSR 1966, pp. 351-2; Draudin 1959, p. 21).

6 Anfimov 1969, pp. 175-6; Istoriia Estonskoi ssR 1966, pp. 69-8o, 352-3, 361; Vilks 1962, pp. 83-7.

7 Koval'chenko and Borodkin 1979, p. 87; Siilivask 1975, p. 65. 


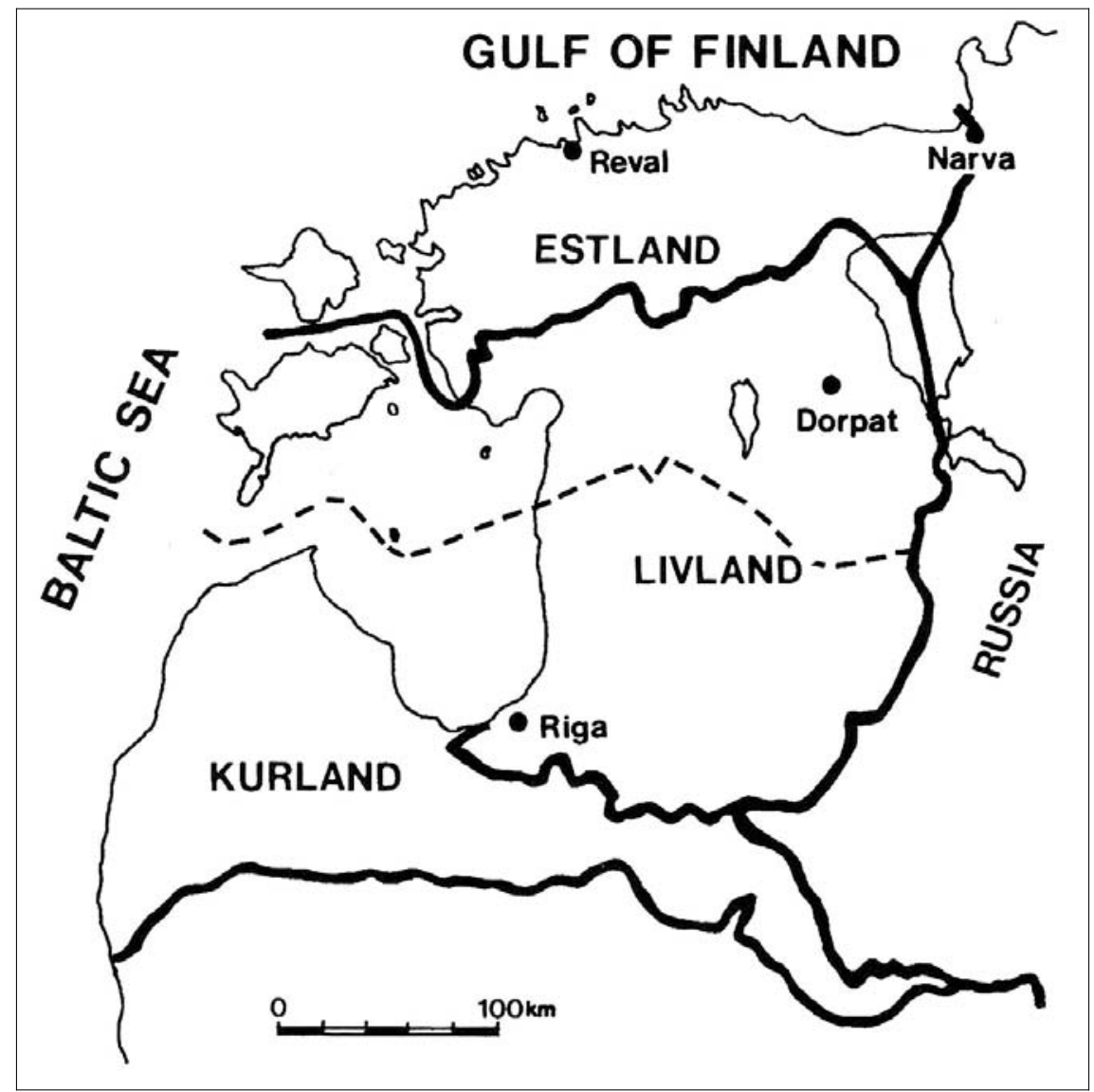

MAP 10

The Baltic Provinces (Estland, Livland, Kurland) and the border between Estonia and Latvia after 1917

than in Germany, and traditional methods of exploitation - of squeezing surplus out of the peasantry - lingered, despite the rapid expansion of new, capitalist ones. As production intensified, the Baltic barons sought to maintain their position by continuing to impose various traditional obligations and by using strong political methods to keep the labour force on the land. In a word, "labourrepressive' trends toward commercial agriculture dominated. These were guaranteed by the Russian state, which was actually, to use Barrington Moore's terminology, an agrarian bureaucracy. The estate owners depended on the central authority for the extraction of the peasant surplus. ${ }^{8}$

8 Koval'chenko and Borodkin 1979, pp. 78, 86-91; Anfimov 1969, pp. 175-6, 36o-81; Saat and 
The Germans came to dominate Baltic society through the agreements they had concluded with representatives of Peter the Great at the beginning of the eighteenth century and which they were able to maintain in essence until 1917. In annexing the former Swedish provinces, the emperor had granted them extensive self-rule, thereby guaranteeing the rights and privileges of the German nobles and burghers - an expedient that assured upper-class cooperation, exactly as it would in Finland one century later with the Swedish-speaking upper classes. The agreements guaranteed the nobles an oligarchic system of government, the German judicial system, the use of German as the official language, and control over the church, which was Evangelical-Lutheran. In each of the Baltic Provinces, the Landtag, or the assembly of the province's nobility, functioned as the highest administrative organ. Local government was also in German hands - in the cities through guilds and councils, and in the countryside through parishes led by German pastors. Much like Finland, then, the Baltic Provinces were in the interface between two established states: they had an alien upper class whose position was first guaranteed by the Swedish crown and then by the Russian autocracy. ${ }^{9}$

The German estate owners may have dominated the capitalist transformation, ${ }^{10}$ but commercialisation occurred in another form as well, as the landowning peasantry increased in importance. In the 1810 s the Baltic serfs had been formally emancipated, and during the 185 os and 186 os the Estonians and the Latvians had obtained the right to purchase land. By 1900 an independent peasant class had grown up, with a small Grossbauer stratum at its top. The progress this class made may be seen in the rapid development of a network of economic and professional organisations in the early decades of the twentieth century.11

A conflict existed, then, between the German landlords and the large masses of landless labourers and poor tenants. Hunger for land was common among the latter: the Baltic countryside was 'bound by semi-feudal relationships and suffering from the dearth of land.' ${ }^{2}$ Additionally, a tension developed between the estate owners and the new indigenous peasant proprietors, who were encumbered with mortgage payments. The peasant landowners felt the weight of the former group's privileges and increasingly challenged its authority. The

Siilivask 1977, p. 26; Moore 1966, pp. 420, 434, 459, 473, 478; Istoriia Estonskoi SSR 1966, pp. 69-8o, 352-3; Draudin 1959, pp. 7, 16-17, 31-5.

9 Haltzel 1981, pp. 112-14. Kurland, however, was taken from Poland (in 1795).

10 See Koval'chenko and Borodkin 1979, p. 89.

11 Kahk 1982, pp. 83-104; Kahk and Vassar 1970; Rosenberg 1985; Loit 1985, pp. 64-7.

12 Saat and Siilivask 1977, p. 26. 
prevailing order had lost the support of the upper crust of the peasantry, which was emancipating and organising itself. As Barrington Moore maintains, this is one of the greatest dangers for an ancien régime. ${ }^{13}$

The landless and the poor peasants had ties with the growing industrial working class. After a period of very rapid growth at the beginning of the twentieth century, the Baltic Provinces were among the leading industrialised and urbanised regions of the Russian Empire and a central way-station in commerce with Western countries. Thanks to the region's position as an interface between the West and the interior of Russia, much of the empire's modern, foreign-dominated industry, 'implanted ready-made from abroad,, ${ }_{1}^{14}$ was located there, producing for the internal Russian market. The Baltic Provinces were thus part of Russia in a much stricter sense than was Finland, not only politically but also economically. ${ }^{15}$ Riga, the capital of Livland, specialised in engineering and metallurgy. With 530,00o inhabitants in 1914, it was the fifth largest city of the Russian Empire, and its industrial proletariat was concentrated in large mills and factories. The situation was analogous in Reval, although on a smaller scale. The Kreenholm cotton mill in Narva was reputedly the largest in the world. The labour force required by the swelling industrial centres was recruited above all from among the landless and poor peasantry. In Reval, for example, two-thirds of the population in 1897 had been born elsewhere, with nearly 40 percent coming from the rest of the guberniia of Estland. ${ }^{16}$

In the late nineteenth and early twentieth centuries, an indigenous bourgeoisie emerged, made up of merchants, minor officials, artisans, and a professional middle class of teachers, lawyers, and physicians. The clergy did not figure prominently in the formation of the native middle class owing to the Germans' hold on the church. ${ }^{17}$

All in all, late nineteenth-century capitalist development created various groups of Estonian- or Latvian-speakers who were increasingly opposed to the existing system of (German) domination: in the middle and upper echelons of society, the peasant proprietors, the urban and rural bourgeoisie, and the middle classes were obvious challengers. At the same time, the industrial work-

\footnotetext{
13 Istoriia Estonskoi SSR 1966, pp. 71-2, 83, 362-4; Draudin 1959, pp. 16-17, 25; Balevits 1962, pp. 171-3, 177, 196-7; Moore 1966, p. 474 .

14 Pollard 1981, p. 240.

15 See Karma and Köörna 1977, pp. 50-62.

16 Vilks 1962; Karma 1963, pp. 110-20, 335-47; Pullat 1976, p. 53; Schram 1957, pp. 55-6o; Pollard 1981, pp. 240-1.

17 Kruus 1935, pp. 131, 179-81; Plakans 1981, pp. 248-9; Jansen 1985, pp. 48-9.
} 
ing class, drawn primarily from the lowest strata of the peasantry, grew rapidly and came to be concentrated in a few large centres. And of great importance, all the native groups were highly literate.

The class structure here differed fundamentally from that in Finland. In the nineteenth century both Finnish and Baltic societies were predominantly agrarian, but in Finland the prospering indigenous peasantry was the dominant landowning class. Consequently, the peasant landowners' relationship to the crofters and the landless became the prime source for social conflict in the late nineteenth century. These landowners, together with the increasingly Finnish-speaking upper classes, played a central role in the process of national integration. Together they introduced, in the form of Fennomania, an agrarian 'civic religion' which guided the integration of the state.

In the Baltic Provinces, the independent peasantry remained small and suffered greatly from the dominance of the German landowners. There, the peasant proprietors played a significant role in the national movement for selfassertion and liberation from the 186 os and 1870 os on - that is, almost immediately after they had obtained the right to own land. Whereas in Finland during the last decades of the nineteenth century the wealthy peasants were a distinctly conservative force, in the Baltic Provinces they were pivotal in challenging the prevailing order. They came into conflict much more with the dominant German classes than with the working classes because they did not have an established position in the local political and economic structure. The economic and social aspect was very pronounced in their nascent opposition, and the anti-German struggle was considered more important than opposition to administrative Russification from the 188 os to $1905^{18}$ The emerging indigenous middle classes, too - particularly the teachers, who were often of peasant origins - played a central role. Moreover, the elimination of the prevailing order was certainly in the interest of the poor and landless peasants, and the industrial workers as well. ${ }^{19}$

This is not to say that the various indigenous groups shared common class interests. Rather, it illuminates the point made in Chapter 5 about the preconditions for movements of national self-assertion and liberation, that mobilisation across class boundaries - the creation of an interclass community - is essential. In the early phase, clearing the way for social and national liberation in the

18 Kruus 1935, pp. 133, 153; Plakans 1981, pp. 225, 241, 255-7. Toivo U. Raun says (1981, p. 340): 'Before the Revolution of 1905 , the great majority of the [Estonian] intelligentsia and the masses regarded the administrative [if not cultural] Russification as an important means to break Baltic German hegemony over local institutions'.

19 Hroch 1968, pp. 72-80; Kruus 1935, pp. 133, 181-7; Plakans 1981, p. 249. 
Baltic Provinces fell to the strongest indigenous groups - mainly to the middle classes and the peasant proprietors, as Miroslav Hroch suggests in his study.

What the coalition was to do in the later phases of organisation and mobilisation is, however, quite another question. In the Baltic Provinces, the independent peasantry and the middle classes, by contributing to the challenge against the prevailing order, were actually opening the way for a more radical protest. It was argued above that the temporal conjunction of the rise of the peasantry and the emergence of popular organisations, including the worker movement, lent popular legitimacy to the latter in Finland. ${ }^{20}$ In a sense this appears to have been true in the Baltic Provinces as well: the peasant landowners and the indigenous (petty) bourgeoisie took the lead in a movement which nevertheless included, at least in principle, the indigenous working classes. ${ }^{21}$ But whereas in Finland this coincidence ultimately served to integrate the popular classes into the state, in the Baltic Provinces it opened the way for a much more thorough challenge, one that grew partly out of the national movement itself.

In the Baltic Provinces the national movement was unambiguously a liberation movement; it was also anti-clerical because of the German dominance of the church. The adoption of a socialist ideology seems to have been easier there than in Finland. Socialist propositions became increasingly popular in the 1890 s, notably among the Latvians, as the urban intelligentsia and other middle-class groups grew. By this time, continuing differentiation within the peasantry had created a more discernible proletarian population in agriculture, and an industrial working class was emerging in the big cities. Moreover, the indigenous groups were still excluded from local political institutions. A new, more radical generation of intellectuals was willing to include the proletariat and semi-proletariat in the national movement. ${ }^{22}$ Among the Estonians, then, two main groupings gradually emerged, and among the Latvians the entire movement experienced considerable radicalisation.

Among the Estonians, the bourgeois-national movement was based on the bourgeoisie and wealthy peasantry, with the university town of Dorpat serving as its main centre. The movement's aim was to overcome the Germans peacefully and gradually to replace them with an Estonian landowner class and an Estonian bourgeoisie that would dominate local political institutions. But another, more radical centre grew up in the industrial city of Reval. This movement had various tendencies, including social democratic ones inspired by

\footnotetext{
20 This was originally Francis Castles's idea (1978, p. 14); see above, Chapter 6.

21 Kruus 1935, pp. 181-2.

22 Plakans 1981, pp. 254-62; Kruus 1935, pp. 188-91.
} 
German and Russian socialism (the radical currents of Russia being far better known here than in Finland). Unlike the more conservative movement, this grouping of intellectuals attempted to unite the radical petty bourgeoisie and the urban and rural working classes, which all suffered, their very different class interests notwithstanding, from the same political oppression. In 1904 this group, in coalition with local Russians, won control of Reval in the municipal elections. ${ }^{23}$ It is important to note that, although Marxist-inspired currents ran through the radical wing, this was not a socialist movement. Nevertheless, the Estonian intellectuals were more susceptible than the Finnish to socialist ideas. Besides the two nationalist tendencies, there was also an unequivocally socialist group of intellectuals in Dorpat, with its own journal. ${ }^{24}$ 'The casual circumstance that the social problem is at the same time a national one lends the movement its singular coloring. [The coincidence of these two problems] rendered excellent service to the Social Democrats', a German professor, writing on the Baltic Provinces, bitterly pointed out a little later. ${ }^{25}$ In an opposite perspective, this remark means that because of severe oppression along national lines, the radical bourgeoisie was able to attract the Estonian working classes and retard the development of their class consciousness. ${ }^{26} \mathrm{In}$ any case, a part of the national movement clearly had a radical hue.

Among the Latvians the process went much further. In the 189os the socalled New Current emerged, attracting the most active representatives of the younger generation and soon becoming the dominant intellectual movement. Ideologically it drew primarily on German social democracy, and the national emphasis was much less evident than in the Estonian movement. In 1904 the Social Democratic party was founded from within the New Current; this party immediately surpassed all other Latvian political groupings, rapidly gaining support from the urban working class. ${ }^{27}$

All in all, then, in the Baltic Provinces both the class structure and the character of the local polities tended to radicalise the national movement. The class

23 Kruus 1935, pp. 182-91; Nodel 1963, pp. 123-4, 129, 133-4. The two tendencies were led, respectively, by Jaan Tōnisson and Konstantin Päts.

24 Kruus 1935, pp. 191-2. There had already been a radical national current in the 188 os when socialist ideas were put forth (Istoriia Estonskoi ssR 1966, pp. 217-18, 236-8; Nodel 1963, p. 118).

25 The Baltic-born T. Schiemann, writing after the 1905 revolution in Russia (cited in Meiksins 1943, p. 25).

26 Istoriia Estonskoi ssR 1966, pp. 405-6.

27 Germanis 1974, pp. 52-3, 149; Ezergailis 1974, p. 114. There was also a more nationalist radical group, which based its ideology on the interests of the Latvian working class, but it remained weak (Germanis 1968, pp. 27-8). 
structure bore deep marks of the feudal past, and the weak local polities were much more open to Russian influence than was the case in Finland. Equally important, the indigenous groups here had great difficulty penetrating into established political institutions.

It is in this context that the third condition - the presence of an upper class that was alien but not of metropolitan nationality - played its role. In Finland the Swedish-speaking upper class, first, had no monopoly on the ownership of land but had to reckon with indigenous peasant landowners; and second, it had vested interests in the consolidation of the already existing state. Consequently, it almost willingly nationalised itself, greatly facilitating the process of national integration. In other words, in Finland the combined effect of the two other conditions, agrarian class structure and political autonomy, tended to neutralise the effect of the superimposition of national and social boundaries within the country. The Baltic German upper class had no comparable reason to surrender to the indigenous challengers, thanks to its class domination, which was embodied in (weak) local political structures. It therefore seems that in the Baltic Provinces, unlike in Finland, the combined effect of the three conditions served to generate wide opposition to the local upper class and to unite the radical challengers with the anti-tsarist Russian groups. These features became more salient in 1905 and 1917-18.

Revolution in the Baltic Provinces, 1905 and 1917-18

In 1905 and 1917-18, although the opportunity for collective action was rather similar in Finland and in the Baltic Provinces, the structural and institutional conditions varied, and with these also the basis for organisation and mobilisation. The question then is, what sort of working-class movement emerged in the Baltic Provinces and under what conditions was it to act in $19{ }^{\circ} 5$ and in $1917-18$ ?

The 1905 challenge found 'a fully prepared ground' 28 in the Baltic Provinces, where several Estonian and Latvian groups saw it as a chance to alleviate their specific grievances, whether economic, political, or cultural. The unrest began with large-scale strikes in the major cities, immediately after January's so-called Bloody Sunday massacre had provoked a strike in St. Petersburg. ${ }^{29}$ The indus-

\footnotetext{
28 Kruus 1935, p. 200.

29 For the sake of conformity, all dates to the end of 1917 are provided according to New Style, although in the Baltic Provinces, unlike Finland, Old Style was used in this period.
} 
trial proletariat took the lead, but thereafter the countryside followed. Tenant farmers wanted the vestigial forms of corvée to be abolished and the tenancy agreements to be revised; the landless demanded better working conditions and better wages. Other peasants, except the uppermost stratum, also participated in the movement. ${ }^{30}$ Rural unrest climaxed in the summer and autumn, and in the Baltic Provinces the whole revolutionary movement took on a strong agrarian flavour. Increasingly the poor and landless peasants played the most active role - a feature that differentiated the region from the interior of Russia, where middle-peasant unrest, to use Eric Wolf's terminology, predominated. Lands were confiscated, and the expropriation of all noble, state, and church land was demanded. In the fall jacqueries occurred: nobles were killed, manors burned, records destroyed, churches sacked. The destruction was much more widespread in the Latvian part of the Baltic Provinces, where the German presence was larger. There, 38 percent of the estates were destroyed or damaged, compared to 19 percent in the Estonian countryside. ${ }^{31}$

Among the organised political groups, the Social Democrats and the radical wing of the Estonian nationalist movement gained ground. Demands were made for universal suffrage, the convocation of a constituent assembly in Russia, and the rights of free speech and free assembly. In the autumn the overthrow of the autocracy, the supply of arms to the masses, and the abolition of taxes were added to the other claims. In many districts elementary education in Estonian and Latvian was reintroduced for the first time since its suspension during the cultural Russification of the previous decades. ${ }^{32}$ In the Latvian areas the Social Democrats, with their main base in Riga, definitely took the lead. Among the Estonians the corresponding process was slower and less complete, but during the latter part of 1905 both the Estonian Social Democratic party (founded only in this year) and the Estonians associated with the Russian Social Democrats operated quite openly. ${ }^{33}$ They alone agitated for the continuation of the revolution, surpassing the radical group of the nationalists, who dominated the city council of Reval. But in the earlier months of 1905 revolutionary demands grew louder among the radical nationalists, too, and their majority envisaged, for national reasons, cooperation with the revolutionary movement in Russia. In the All-Estonian Con-

$30 \quad$ Karjahärm and Pullat 1975, pp. 48-58; Kruus 1935, pp. 198-202; Ezergailis 1974, pp. 5-6.

31 Von Pistohlkors 1978, p. 229; Draudin 1959, pp. 7-8, 34, 37-9, 47; Ezergailis 1974, pp. 6-7, 13-14; 23; Karjahärm and Pullat 1975, pp. 117-24; Kruus 1935, pp. 198-202, 208; Raun 1984b, pp. $461-3$.

32 Draudin 1959, pp. 44-6; Ezergailis 1974, pp. 6-7, 13-14; Kruus 1935, pp. $200-8$.

33 Karjahärm and Pullat 1975, pp. 106-7; Raun 1982, p. 52; Raun 1984a, pp. 132, 137. 
gress in December, the major division was between the radical nationalists and the socialists on the one hand, and the more conservative nationalists on the other. Although their economic and social demands differed greatly, the mainstream of all three orientations stressed Estonian cultural and administrative autonomy. ${ }^{34}$

The socialists were supported by urban intellectuals and workers; the latter, who had many connections in the villages, were then instrumental in extending political organisation into the countryside. In the autumn, trade unions, other associations, and even elected committees and popular militias were set up in the cities and the countryside. ${ }^{35}$ The agrarian movement seems to have had more of a socialist character in the Baltic Provinces that in most of the other gubernii. In Lenin's assessment, the Latvian proletariat and peasantry played a leading role in the whole revolutionary movement of $1905 .{ }^{36}$ And G.T. Robinson states in his classic account that the social democrats 'attained their greatest success' in the Baltic Provinces. There, where 'agriculture was organized so largely on a capitalistic basis ... the mass of landless agricultural laborers furnished just the soil that the Social Democrats liked best to cultivate. ${ }^{37}$

But the devastating agrarian revolt soon expanded beyond the organisational capacities of the social democrats and other radical groupings: their attempts to restrain disorder and pillaging met with little success. In the Estonian areas, urban workers from the largest cities joined the peasants in the jacqueries, or even took the initiative in starting the violence. In the Latvian countryside the destruction of landed estates appears to have occurred independently of urban support; the socialists also disagreed with the peasants who had confiscated land. ${ }^{38}$

A severe repression followed the re-establishment of imperial authority. At least 300 Estonians were murdered or sentenced to death, and the popular organisations were proscribed. Among the Latvians, 2,000-2,500 persons were executed and 5,000 exiled because of their active role in the revolutionary

34 Von Pistohlkors 1978, pp. 231-7; Karjahärm and Pullat 1975, pp. 113-16; Kruus 1935, pp. 2038; Raun 1981, pp. 320, 338-9; Raun 1982, pp. 62-5. As to administrative autonomy, the Bolshevik-oriented Estonian Social Democrats differed from the others in their insistence on an all-Russian, centralist perspective (Raun 1984a, pp. 137-8).

36 Germanis 1974, pp. 53-4; Apine 1970, pp. 213-14.

37 Robinson 1932, p. $15^{8}$.

38 Kruus 1935, p. 208; Nodel 1963, pp. 143, 152-3; Ezergailis 1974, pp. 6-7, 13-14; Raun 1984b, p. 461. 
movement. Underground activity continued, especially in Latvia, but the popular organisations, which had grown so rapidly, were liquidated. ${ }^{39}$

In both Finland and the Baltic Provinces, the 1905 revolution launched a mass movement that, although supported initially by the industrial working class, quickly spread to the countryside, involving not only the middle strata of peasants but also - or even especially - the landless. At least part of the explanation for the ability of the poorest rural strata to act on their own behalf lies, in both cases, in the sudden collapse of government and in their strong links with the industrial workers.

But then the differences must be examined. The Baltic reaction was immensely more rapid, more spontaneous, and more powerful than the Finnish: large-scale agrarian capitalism, combined with lingering feudal methods of exploitation, created a strong potential for endemic peasant unrest (as in a number of other ancien régime societies). Soon the nationalist bourgeoisie found that they could not control the revolt, and a large proportion of the national bourgeois groups joined the popular challengers (in Estonian areas), or entire middle-class groups were overwhelmed by radical intellectuals from the outset (in Latvian areas) - in both cases, to a much greater extent than in Finland. In the Baltic Provinces, the indigenous bourgeois and middle classes had practically no institutional positions to defend in the local polities. Moreover, the emerging working-class movement did not have effective control over the mass movement. A large-scale socialist organisation was totally unthinkable before 1905, and the notoriously oppressed rural masses could not be organised and disciplined in only a few months. The situation was radically different in Finland, where the Social Democratic agitators' main worry in many areas was how to activate the crofters and landless to vote in the elections of 1907 (a process depicted in Ilmari Kianto's 1909 novel The Red Line) ${ }^{40}$

Lastly, in the Baltic Provinces the main non-national target was initially the local German upper class, whereas in Finland it was the Russian autocracy. The intrasocietal aspect with national overtones was more pronounced in the Baltic Provinces than in Finland, where the Swedish-Finnish division was of secondary significance. What counted in Finland was the defence of the Finnish polity and, for the working-class movement, its internal transformation. The Social Democrats' national orientation was strong and authentic. In the Baltic Provinces, in contrast, what counted was the removal of the (German) economic and political oppression, which soon led to demands for radical political

\footnotetext{
39 Karjahärm and Pullat 1975, pp. 150-3; Kruus 1935, pp. 210-11; Germanis 1974, pp. 56, 77-8; Karjahärm, Krastyn', and Tila 1981, pp. 74-6.

40 Cf. Hamalainen 1978, pp. 66-7.
} 
reforms on a pan-Russian scale but only secondarily to a call for the reversal of Russification. Given these ends, connections with Russian revolutionaries were natural.

In early 1917 the popular groups and the radical, notably socialist, challengers were in a situation very similar to the one of twelve years earlier. Again the masses were unorganised and entirely unrepresented in the Baltic political structures, and again the radicals remained scattered, with no established links to popular groups. The Latvian Social Democrats had been forced to go underground. The Estonians, for their part, had made a 'quantum leap' toward much greater political awareness and sophistication after the revolution of $1905,{ }^{41}$ and the most influential current, the radical Young Estonia cultural movement, was clearly socialist in hue. The most marked institutional difference between 1917 and 1905 lay in the position of the national bourgeoisie, and even this distinction was confined primarily to the Estonians. Estonian statemaking and nation-building had progressed from about the mid-189os on, but they gathered momentum after the first Russian revolution: by 1914 the Estonian nationalists had won control of six of the ten major cities in Estland and northern Livland, thereby obtaining a definite share of political power. But this was just one aspect of how the locus of Estonian public life shifted to the cities. A network of cultural and professional organisations also grew up, and Estonian culture made rapid progress in literature and education as well. At the same time, agricultural societies and cooperatives spread throughout the countryside. In the political sphere, the conservative nationalists' Estonian Progressive People's party, founded in 1905 and the only legal Estonian party until the February revolution, played the main role. ${ }^{42} \mathrm{~A}$ civil society, based on the national bourgeoisie, the independent peasantry, and the middle class, was clearly consolidating itself.

Unlike Finland, the Baltic Provinces were directly affected by the war. Estonian and Latvian conscripts served in the Imperial Army, and, more important still, with the continuation of the war both nationalities acquired their own troops. The Latvian Riflemen's battalions, later renamed regiments, were created in 1915 after the successful German counter-offensive. The same occurred in Estonia, but only after the February revolution, and then on a smaller scale. ${ }^{43}$ In any case, during the critical summer and autumn of 1917, both nationalities were to have a domestic apparatus of violence. Also, the German menace was far more real in the Baltic regions than in Finland. By March 1917, half of

41 Raun 1982, p. 65.

42 Kruus 1935, pp. 193-6, 219-2o; Raun 1981, pp. 308, 322, 332, 339; Raun 1982, pp. 65-71.

43 Ezergailis 1974, pp. 167-9; Kruus 1935, pp. 236-7. 
Kurland was occupied and Riga evacuated; moreover, the German occupation forces were nationally close to the local - German - upper class. Finally, these regions suffered economically much more than Finland. But while the war certainly hurt the Estonians and the Latvians more than the Finns, short-term differences are presumably of secondary importance when explaining variations in the revolutionary process. As Andrew Ezergailis points out in his study of the Latvian revolution, "The war did not create Latvian radicalism; it was there already in 1905. ${ }^{.44}$ Long-term factors conditioned the Baltic developments in 1917 in very essential respects.

Of the two nationalities, closer to the Finns in their political development in 1917 were the Estonians (as they incidentally were in a linguistic and geographical sense, too). Not surprisingly, it was the nationalist Estonian Progressive People's party - the only organised indigenous political force - that took the initiative after the February revolution. Already in April the bourgeois groups succeeded in establishing self-government for the Estonian areas. The Provisional Government of Russia abandoned the local Germans completely and formed a new guberniia out of Estland and the Estonian-speaking part of Livland, with its own governmental organ, the Diet. In the elections of early June, the bourgeois parties gained half the seats, the other half being divided between the Estonian Socialist Revolutionaries and the social democratic groupings. Although these parties had originated in earlier years and subsequently developed connections with the revolutionary Russian parties, they were all organised or reorganised only after the February revolution. ${ }^{45}$ The Bolsheviks gained just one seat. It is true that the electoral system was based on indirect (if universal) suffrage, that it disfavoured the industrial proletariat in the short run, and that the turnout was low, but this result gives a fairly accurate picture of the parties' relative strength in the spring. ${ }^{46}$ In other words, the well-organised bourgeoisie was in the best position to exploit the opportunity created by the war, but in a few months more radical indigenous challengers were able to draw even with it.

Soviets were now being set up, first in towns and then, to a lesser extent, in the countryside, as elsewhere in the empire. The Socialist Revolutionaries dom-

\footnotetext{
$44 \quad$ Ezergailis 1974, p. 204.

45 Raun 1981, pp. 339-40; Raun 1982, pp. 70-2.

46 Arens 1978, pp. 19-23; Kruus 1935, pp. 230-4; Saat and Siilivask 1977, pp. 63, 65, 76-85, $100,140-6,163$. Urban deputies to the Diet were elected in the late summer and autumn only (see Arens 1978, pp. 23, 26). The Estonian Socialist Revolutionary organisation at first included both Russians and Estonians, but during the summer the Estonian section broke off and became the overwhelmingly stronger faction (Saat and Siilivask 1977, p. 104).
} 
inated all the soviets except one in the spring and summer, as they dominated political activity among the Russian troops that were stationed in Estonia. During this initial phase the Russian soldiers and sailors played a significant role in the principal soviets. The Estonian participants and supporters were mainly factory workers: the soviets were linked to collective action in the towns, action that had begun with the revolution in Petrograd through the form of strikes, demonstrations, and trade union activity. As in 1905, poor peasants, cottagers, and the landless figured among the rural challengers, demanding the confiscation and distribution of noble, state, and church lands, reduction of working hours, and higher wages. ${ }^{47}$

The Estonian polity, established at last, was valued by the non-bourgeois groups, and the other parties gradually came to accept the bourgeois national programme of substantial governmental autonomy in a federal Russia. In the spring and early summer there were no irreconcilable disagreements within the Diet or between it and the majority of the soviets, with the notable exception of Reval. ${ }^{48}$ It is indicative of the limited scope of conflicts that a new police force, replacing the tsarist police, was successfully organised in most cities by the town councils and town soviets. In the countryside the police force was administered by the new organs of local government that emerged linked to preparations for the Diet elections. ${ }^{49}$

But, as in many other parts of Russia, a dual power began to take shape. During the summer and autumn the masses were so thoroughly radicalised that the non-bourgeois parties were largely overwhelmed by a more extreme challenge. The Estonian Bolsheviks, starting from modest beginnings in the spring, were able to take over the soviets and organise the masses, first in the cities, but then even in the countryside. Significantly, they gained control of the national troops in September and early October, a couple of months after the troops had been created..$^{50}$ In August, Bolshevik membership figures surpassed those of all other parties, thanks largely to the support of urban workers. The Bolsheviks became the largest party in the soviet of Reval in August and gained an absolute majority in September. The same development occurred in soviets in a number of other cities. In the municipal elections, too, the Bolsheviks made increasing

47 Saat and Siilivask 1977, pp. 40-57, 63-4, 67, 116-17, 126-31, 178; Arens 1982, 295-301.

48 Saat and Siilivask 1977, pp. 86, 100-4, 340-2. The first serious controversy occurred in early June when the soviet of Reval unsuccessfully attempted to push aside the local Estonian government and to delay the elections to the Diet (Saat and Siilivask 1977, pp. 146-52; Kruus 1935, p. 231).

49 Arens 1978, p. 24.

$50 \quad$ Saat and Siilivask 1977, p. 235; Kruus 1935, p. 239. 
progress as the summer wore on and autumn approached. ${ }^{51}$ In the elections to the Russian Constituent Assembly, two weeks after the October revolution, the Bolsheviks gained 40 percent of the vote and became by far the largest party in Estonia - a performance equalled or surpassed in very few other gubernii. The bourgeois parties won only 29 percent of the vote, with the remaining $3^{1}$ percent divided among various social democratic parties and the Estonian Socialist Revolutionaries. In all electoral districts but one, the Bolsheviks gained more votes than any other party. ${ }^{52}$

The Bolsheviks gained ground mainly at the expense of the other left-wing parties. In half a year they were able to defeat their competitors not only in the cities but also in the rural areas; indeed, in the Constituent Assembly elections they became the largest party in the countryside.

How did all this happen? Crucial, of course, was the Bolsheviks' ability to capture the soviets - that is, the key loci of popular organisation - and the national Estonian troops. But their success both in the soviets and among the masses would not have been possible had their programme not strongly corresponded to popular grievances. Their consistent anti-government and anti-war line, together with their revolutionary demands, won them large-scale support among the urban workers; and their agrarian programme for expropriating the big properties without indemnification, in accordance with the so-called April theses of Lenin, met with resounding approval among the 'toiling peasantry'. In August they extended the list of agrarian enemies from the nobles, the church, and the state to the wealthy Estonian peasantry. Attacking the landlords more uncompromisingly than any other party brought considerable support for the Bolsheviks, even if their eventual plans to distribute expropriated lands remained vague and at best limited. ${ }^{53}$

When the revolution occurred in Petrograd in early November, the local Bolsheviks took power in Estonia. Unimportant as this move was in terms of the Russian Constituent Assembly elections, in a larger sense it was a watershed. The Estonian Bolsheviks' national programme had been limited, aiming at self-determination and local autonomy with an Estonian administration and school system, whereas the other parties had advocated an autonomous Estonia within a federative Russia. ${ }^{54}$ The Bolsheviks' electoral success seems to indicate the secondary role of national considerations. But after the Bolshevik takeover the national question became salient: before its dissolution by the

$5^{1} \quad$ Saat and Siilivask 1977, pp. 189-96, 212-16, 228-30; Kruus 1935, pp. 234-5, 239.

$5^{2}$ Saat and Siilivask 1977, pp. 257-6o; Radkey 195o, pp. 78-8o.

53 See Arens 1982, pp. 303-8; Saat and Siilivask 1977, pp. 182-4, 200, 235-6, 325-6.

54 Saat and Siilivask 1977, pp. 340-2. 
Bolsheviks in the end of November, the Estonian Diet declared itself entitled to wield supreme power, and all non-Bolshevik parties included, more or less clearly, Estonian independence in their programmes, thus emphasising their distinctiveness from the Bolsheviks. ${ }^{55}$ It was presumably this turn that led to the defeat of the Bolsheviks in the elections to the Estonian Constituent Assembly in January 1918. Also the poor peasants' thirst for land seems to have been detrimental to the Bolsheviks: in December and early January it had become clear that the Bolsheviks intended to preserve the large estates and transform them into collective farms. ${ }^{56}$ The turnout rose to 75 percent (from 57 percent in November), but the Bolsheviks' proportion declined, and the elections were stopped. They lost mainly to other leftist parties, especially in the countryside. ${ }^{57}$ The tide perhaps began to change, then, following the October revolution. But what remains important to note is the Bolsheviks' phenomenal capacity to supplant the more moderate Left within just a few months in the summer and autumn of 1917.

The Latvians were won over to revolution more easily and more thoroughly. Already in 1905 the Social Democrats had become the most powerful political force, and they maintained this position throughout the later years of clandestine activity. In April 1917 the party, which had earlier joined forces with the Bolsheviks, merged with them more definitely than ever. This Social Democratic party took command immediately after it came above ground in March, and it generally won the majority of both the urban and the rural vote in the various elections held in the summer and the autumn, reflecting weak popular support for the Latvian Mensheviks and the bourgeois parties. ${ }^{58}$ As a matter of fact, the Latvian areas were the first in the whole of Russia to be bolshevised, and arguably the party would already have been able to seize power in the summer had there been no Russian troops. Of crucial importance in this respect was the early dominance of the Riflemen's regiments by the Bolsheviks. ${ }^{59}$

Just as the outbreak of revolution in Estonia and Latvia was determined by the international power constellation, so too was the final outcome. In the power vacuum following the February revolution, the local revolutionaries were able to win considerable popular support and then, at the time of the takeover in Petrograd, to seize power. But the German troops drove the local Bolsheviks out in early 1918, and bourgeois organs declared their countries

Aun 1982; Saat and Siilivask 1977, pp. 374-7; Kruus 1935, pp. 240, 244.

Saat and Siilivask 1977, pp. 329-32, 381.

Saat and Siilivask 1977, p. 379; Kruus 1935, pp. 242-3.

59 Ezergailis 1974, pp. 134, 179-83, 204, 251; Ezergailis 1982. 
independent. After Germany's collapse, the Entente guaranteed the survival of the new, bourgeois republics as a part of their efforts to make the Baltic area 'a barbed wire entanglement' ${ }^{60}$ protecting the West from Bolshevik Russia. The German troop withdrawal was delayed until the local bourgeois governments could establish themselves and the Entente and neighbouring Western powers could give material and other assistance. This greatly contributed to local ability to repulse the attacks by Bolshevik troops, which were partly - or, in the Latvian case, overwhelmingly - composed of indigenous groups. ${ }^{61}$

To conclude, the context - the power struggle in Eastern Europe in 191420 - was common to Finland, Estonia, and Latvia alike. Decisive for each was the collapse of the two main warring partners, first Imperial Russia, and then Imperial Germany. In every case the revolutionary situation was provoked by the collapse of Russian autocracy, and in every case German troops defeated or at least greatly contributed to the defeat of the revolution. Furthermore, all were saved from German domination by the subsequent defeat of Germany a little later. And finally, the victorious Western powers, in pursuing their own interests, guaranteed the survival of the new states (in the case of Estonia and Latvia) or influenced the orientation of internal politics (in the case of Finland).

The similarity of the international context conceals marked differences in the way the revolutionary process took place, however. The close parallel with pan-Russian revolutionary developments was obvious in the Baltic Provinces. Actually, the revolution in Estonia and Latvia in the autumn of 1917 was a part of the October revolution itself, whereas most of the Russian influences in Finland were mediated indirectly and primarily affected the Finnish state's capacity to maintain order. Also, the Baltic Provinces, like the rest of Russia, had been waging war for three years, with ensuing suffering and economic deterioration.

These differences amount to saying that there was no separate polity in the Baltic Provinces, such as there was in Finland. The corresponding structures were more modest, and the indigenous groups' position in them precarious at best. The radical tendency in the Estonian and Latvian national movements was attributed above to this condition. The Latvians' position in the polity was especially weak, and so national integration never became a key task for them, as it did for the Finnish nationalists. The weakness of local polities also denied the Estonian and Latvian radical parties the opportunity to organise openly; the Social Democrats were under the same repression as in the interior of Russia.

6o As Clemenceau put it (cited in Meiksins 1943, p. 172). See also E. Anderson 1977, pp. 340, $350,363,376$.

61 Schram 1957, pp. 36-49; Kruus 1935, pp. 258-9. 
In these circumstances the Estonian - not to speak of the Latvian - Bolsheviks were able to head the mass movement in 1917 by capturing the support not only of the industrial workers but also of the unorganised poor and landless peasants. The other, shallowly rooted left-wing parties were pushed aside rather easily, at least momentarily, when the Bolsheviks turned against the indigenous bourgeoisie and wealthy peasantry. The Latvians and the Estonians followed the 'idealised revolutionary sequence' much more closely than the Finns. True, in all cases the process was launched by the collapse of imperial authority in March. But the consequences were different in Finland, thanks to the distinctiveness of the Finnish polity. The restoration of Finnish autonomy, together with growing self-assertion in the face of the Provisional Government, left the Finnish state totally without control of the concentrated means of coercion within the population. The process was completed by the dismissal of the 'Russified' police. In Estonia and Latvia, the main authority rested instead above all with the Provisional Government, which maintained that authority up to the autumn. The February revolution progressed from gradual mobilisation of contenders, through a rapid increase in the number of people accepting their claims, to the government's incapacity to suppress the alternative coalition. Finally, power was seized by the Bolsheviks.

This development resulted not only from the weakness of the local polities; the Baltic class structure was at least as important. In 1917 the landless and poor peasants, suffering from a mixture of capitalist and semi-feudal methods of exploitation, were again, as in 1905 , ready to dynamite the existing order. The industrial working class, moreover, being concentrated in a few big centres, above all in Riga, was in much the same position as the workers in Petrograd and Moscow.

All this places the Finnish situation in 1917 in perspective. First, in the Finnish polity, the socialists shared political power when they started on the road to revolution. Second, in Finland the reformist working-class movement was able to maintain its grip on the masses throughout 1917: the party effectively held the radicalisation in check. The militants took over the worker security guards only after a long struggle - and only after the bourgeois counteroffensive had become evident. In Estonia, in contrast, the local Socialist Revolutionaries and social democrats, who had won the overwhelming majority of the proletarian and semi-proletarian vote in the spring, were rapidly eliminated by a more revolutionary challenger. In Latvia the process was faster and still more complete. 
The generalised collapse in 1918 created favourable opportunities for popular collective action in East-Central Europe, the Balkans included. The crucial issues were again the character of the worker movement before World War I on the one hand, and the impact of the war on local power structures on the other. These two factors are presumably central in accounting for the local challengers' ability (or inability) to seize power in a sudden power vacuum.

The Habsburg monarchy provides an illuminating example of the fortunes of a minority region that, at least politically, was far more dependent than Finland: the Czech lands. While these had a strong linkage to a historically remembered polity, the Kingdom of Bohemia, administratively they were divided into three parts: Bohemia, Moravia, and Austrian Silesia. The Czech territory was entirely within the boundaries of the monarchy, making the Czechs a pure example of autonomist nationalism. In terms of class structure, the region bore a certain resemblance to Finland. Bohemia was the most industrialised part in the whole empire, and the Czech lands had an industrial working class, a class of prospering peasants, and a high level of elementary education. ${ }^{62}$

The national movement, notably in Bohemia, was directed against the Germanised nobility and the German bourgeoisie. In the 1870 os and 188 os the Czech Social Democrats, a separate section within the Austrian Social Democratic party, had much the same national objectives as the nationalist Young Czechs; then in the 189 os, with the national question generating more and more tension with the Austrian-dominated mother party, they gradually established themselves as a separate party. The national orientation was facilitated by radical tendencies in the nationalist movement, represented particularly by various bourgeois and lower-middle-class groups having their origins in the peasantry. ${ }^{63}$ In the 189 os the so-called Progressive movement strove to unite social and national aims, and the Czech National Socialist party, supported by the Young Czechs, was founded to compete with the Social Democrats for the worker vote. Despite growing social differentiation among the Czechs, the national flavour persisted in the working-class movement after the turn of the century. In the first Austrian general elections with universal and equal male suffrage, held in 1907, the Social Democrats gained 38 percent of the Czech vote: they seemed indisputably a central force in a possible Czech - or Czechoslovak - polity. During the war, national fervour spread among the work-

$62 \quad$ Pollard 1981, pp. 222-5; Lemberg 1977, p. 323; Orridge and Williams 1982, p. 21.

63 Hroch 1968, pp. 41-61; Koralka 1971, pp. 58-65; Lemberg 1977, p. 324. 
ing people, and socialist slogans in strikes and demonstrations were overshadowed by general enthusiasm for national freedom. In the period immediately preceding the foundation of the Czechoslovak state in October 1918, 'the working people became the main force of the Czech national liberation struggle', believing that an independent state would satisfy their social demands. ${ }^{64}$

There are considerable and illuminating differences between the Czech and Finnish experiences, both in long-term political dependence and in the way the collapse of the mother empire affected the national minority. In the Czech case, social and national oppression largely overlapped, and there was no autonomous polity. National oppression was associated with the dominant metropolitan nationality. The Czech experience, moreover, shows how 'relative over-development' can give rise to nationalist movements for liberation and self-assertion. ${ }^{65}$ Not surprisingly, although both the Czech and the Finnish labour movements were nationalist, nationalism was more pronounced - and presumably more aggressive - in the Czech Social Democratic party.

In Finland, when the metropolitan power collapsed, a separate polity existed and, significantly, the socialists had an important share of the power. There was no Czech polity in which Czech socialists could act and make their influence felt. What occurred in the Finnish case was a contest for power within an existing polity; in the Czech case the struggle was to create a new polity that would grant the Social Democrats a share of the power and make democratic reforms possible. The first and foremost concern of the Finnish socialists was the preservation and extension of democracy; the first concern of the Czech socialists was the establishment of a polity. Thus, differences in the context not differences in revolutionary inclinations or attitudes (which, in fact, were quite minor) - led to varying roles for the Czech and Finnish Social Democrats in 1917-18.

Much of what was just said about Czechoslovakia applies to the rebirth of Poland as well, the large political and economic differences notwithstanding. Common to the two cases was a lack of self-administration, which in the Polish regions was exacerbated by partition among three empires. Deep political dependence was combined with an even more vivid remembrance of a historical polity. The dominant wing of the worker movement, the Polish Socialist party, was markedly nationalist. It was unreasonable to expect that the small revolutionary movement, consisting of Rosa Luxemburg's Social Democrats and the socialist Left, would have been able to penetrate peasant masses in

64 Koralka 1971, pp. 57-65, 69-73 (quotation from p. 73); Droz 1971, pp. $75^{-85}, 87-9$.

65 Nairn 1977, pp. 185-6. 
1917-18 or immediately after. The revolutionaries' inability to co-opt the peasants had been foreshadowed in 1905-7, when the first Russian revolution gave rise to a strong but momentary wave of collective action in the Russian partition. Now for a sizable majority of the organised workers, as well as for a large number of peasants, the rebirth of the Polish state seemed a necessary precondition for all reforms and progress. ${ }^{6} 6$

Hungary, in contrast, was a country where a powerful challenger armed with a revolutionary doctrine and revolutionary long-term objectives existed in early 1919 in a stricter sense than anywhere else in the region. Of all the successor states, Hungary was the least politically dependent. A formal partnership had prevailed in the empire since the Dualism creating Austria-Hungary in 1867. Economically, Hungary was one of the East-Central European regions where one-sided agrarian progress was the core of the process of capitalist transformation, thanks to demand in the more industrialised parts of Europe. In this case the demand resulted from the western parts of the Dual Monarchy, which as the main purchaser of Hungary's products effected a transformation in its agriculture. The agrarian laws of the mid-18oos assured the predominance of capitalist relations in the countryside, that is, the so-called Prussian pattern of development, with noble latifundia on the one side, and a formally emancipated but downtrodden peasantry providing cheap labor on the other. Only at the end of the century did an industrial working class begin to develop, and then mainly in large centres not directly connected with the agrarian population. ${ }^{67}$

These circumstances left their mark on the Hungarian Social Democratic party, which from its inception in 1890 was a movement of the industrial proletariat, rooted in a few main centres, most notably Budapest. No real attempt was made to mobilise the oppressed rural masses, nor was the organisation involved in their revolts after the turn of the century. The party was merely semi-legal and was harassed incessantly by the authorities. Based on the trade unions, it fought for improvements in working conditions and wage increases and, in the political realm, for universal suffrage: in other words, it was 'reformist' and 'revisionist'. Few intellectuals figured in its leadership. In any case, it was the only Hungarian party with links to popular groups. ${ }^{68}$

66 Ajnenkiel 1969, pp. 48-9; Kalabinski and Tych 1962, pp. 204-9, 226-7, 231-2.

67 Berend and Ránki 1974, pp. 31-3, 39-40, 47, 122-9. True, in terms of production there was a connection between the agrarian transformation and industrialisation in that food processing became the leading industry. But at the same time, food processing's share in total employment remained far below its share in production.

68 Erényi 1975, pp. 55-73; Nagy 1967, p. 159; Deák 1968, p. 134; Kenez 1972, pp. 64-5; Király 1977, 407-16. 
The party altered its position dramatically in 1917 as social and economic problems worsened and the October revolution erupted in Russia. Workers' councils were set up, and mass demonstrations, strikes, and trade union activity mushroomed, as did revolts and army desertions. But although the radicals gained some ground, the party leaders remained well in control of the swelling movement and maintained the traditional, non-revolutionary line. The decisive change came with the bloodless bourgeois revolution of October 1918. Lacking a clear strategy - they 'responded to the challenge with a sense of shock' ${ }^{\prime 69}$ the Social Democrats simply acquiesced and formed a coalition government with the bourgeois liberals and radicals. They accepted a secondary role in the new government, despite being practically the only viable political force in the country, having brought together nearly a million organised workers. ${ }^{70}$

The situation was extremely grave for the new republic. Decay in the economic and social fabric had been accompanied by the disintegration of the army and the return of hundreds of thousands of armed soldiers from the front or from captivity in revolutionary Russia. Together with workers, they played a central role in councils and other organisations demanding rapid and thorough social reforms. Moreover, external pressures added to internal ones. In November the government was obliged to sign an armistice agreement that divested Hungary of about half of her former territory, leaving the country vulnerable to an invasion by Romanian, Czechoslovak, Serbian, and French forces. ${ }^{71}$

While the Social Democrats were, with the bourgeois parties, trying to reestablish the authority of the state, a new, revolutionary challenger emerged. The Hungarian Communist party was founded in November 1918, mainly by a group of former prisoners of war returned from Russia, where they had set up a Hungarian group within the Bolshevik party. Their revolutionary programme gave direction and coherence to the radicalised groups, which were by then disappointed with the socialists' policy. Being able agitators and organisers, the Communists rapidly gained ground in the soldiers' organisations and among the active workers, both employed and unemployed, although their numbers were small compared with those of the Social Democrats. ${ }^{72}$

In a few months the socialists found that the fate of the new republic lay increasingly in their hands. With the gradual weakening of the bourgeois parties, they began to dominate the political scene in December 1918. In January the government was reorganised to the socialists' advantage, and in February

\footnotetext{
$69 \quad$ Vermes 1971, p. 36.

70 Vermes 1971, p. 49; Nagy 1967, pp. 16o-1; Tökés 1967, pp. 30-47, 85-7.

71 Tökés 1967, pp. 84-5; Nagy 1967, p. 162.

72 Tökés 1967, pp. 92-122.
} 
the leading Communists were imprisoned. But despite extensive membership and growing power on all levels of central and local administration, the Social Democrats did not succeed in consolidating their position or the authority of the prevailing system (which amounted to the same thing). Internal order was nearing total collapse in February and March. ${ }^{73}$

This situation may be compared with the post-war disintegration in Germany and Austria, where, simultaneously, the social democrats were actually saving the bourgeois states. The Hungarian party, however, lacked the political experience and established membership in the polity that its brother parties had. The Hungarian party was unable to choose between firm action in defence of the prevailing system and adoption of a definitely revolutionary policy; its leaders abhorred the methods of Gustav Noske, but they also rejected the Bolshevik example. ${ }^{74}$ In previous years the party had not gained membership in the polity, but at the same time it had not really been persecuted. As a consequence, it had developed a narrow trade-unionist perspective.

From the Communists' point of view, however, the situation resembled the one in Russia after the February revolution. They looked forward to seizing power from the bourgeois-socialist coalition in the same way the Bolsheviks had taken it from the Provisional Government. This opportunity seemed to present itself in March, when internal disintegration culminated, and the Entente issued an ultimatum that would have opened the way for Czech, Romanian, and French troops to occupy the bulk of the country. The prime minister and other bourgeois ministers felt compelled to surrender power to the only remaining organised force, the working-class parties. Béla Kun and other Communist leaders were released from prison, and on 21 March power was transferred to the Social Democrats and Communists. Not only did these two groups then form a common government, but they also merged into a new, unified Hungarian Socialist party. The far smaller but much more resolute Communist faction gained the upper hand, with Béla Kun becoming the leader of the new Hungarian Soviet Republic. ${ }^{75}$ Thus Hungary followed the 'idealised revolutionary sequence'.

The national emergency helped the revolutionaries to stabilise the military situation temporarily, and in June the Hungarians even extended the revolution into Slovakia. ${ }^{76}$ Four months later, though, the revolution was defeated -a failure in part a result of external pressure, but also of grave errors made by the

\footnotetext{
73 Vermes 1971, pp. 52-4.

74 Vermes 1971, p. 5 o.

75 Tökés 1967, pp. 129, 132-4.

76 See Toma $195^{8 .}$
} 
revolutionaries themselves, who antagonised the rural masses by obstinately advocating large collective estates despite the deep-rooted hopes of the poor and landless peasantry for their own farms. ${ }^{77}$ In other words, although Hungary did not follow the German social democratic example, it did not follow the Bolshevik example, either.

In both Finland and Hungary the nonrevolutionary social democratic parties were driven to revolution. This development occurred under different conditions, however. First, the Hungarian party had been marginal in the political system; because it had no established position in the polity, it was unable, in the tumultuous conditions of 1918-19, to resist the challenge of a more radical party. Thus the Communists could rapidly gain ground, make the socialists accept the revolution, and finally enlist them in efforts to transform society from bottom to top, ${ }^{78}$ a progression reminiscent of the Baltic developments in the summer and autumn of 1917. The Finnish party, in contrast, was deeply rooted in the population and comparatively well entrenched in the political system when the crisis suddenly occurred. It was therefore in a much better position to control the radical but diffuse challenge of the worker guards. It also envisioned a revolution that would extend democracy - but only within the bounds of the capitalist society.

Second, the Hungarian state and society were in a state of dissolution at the time the crisis occurred in October 1918. Hungary had collapsed, and the ruins were left to the socialists simply because no other hope for survival existed. The party had no choice but to take responsibility, first with the bourgeois parties and then, after further deterioration of the situation, with the Communists. It accepted power; it did not seize it as the Bolsheviks had done. The statement of the provisional president, Count Károlyi, on 21 March 1919 is symptomatic: he 'transferred the power to the proletariat of the Hungarian peoples'. ${ }^{79}$

The Finnish state, for its part, had one fatal weakness after the February revolution: lack of control over the means of coercion. Otherwise the state remained effective, and civil society, too, was well integrated and strong. After socialists had penetrated into the very heart of the state, then, the bourgeois state and civil society reasserted themselves, causing the socialists to attempt to hold on to what they had gained in 1917. This was the road to revolution in the Finnish case.

Thus, although at one phase both the Hungarian and the Finnish socialists were in coalition with bourgeois parties, after that their paths diverged. In

77 Tökés 1967, pp. 185-8.

78 See Eckelt 1971.

79 Cited in Toma 1958, p. 203. 
Hungary it was the combination of pressure from the left and fear of internal anarchy and foreign occupation that drove the socialists to revolution; in Finland it was the resolute bourgeois effort to recapture the monopoly on power.

Revolutionary determination on the part of the socialist parties on the eve of the sudden collapse was not of primary importance. There was no such determination in any serious sense in either the Finnish or the Hungarian parties when the Russian and Habsburg empires collapsed. What mattered most was simply the existence of well-organised working-class movements. In both cases a crisis in the state finally drove the challengers to revolution, irrespective of their initial conceptions. Characteristically, in both Finland and Hungary the socialists largely supported the decision about the revolution after it had finally been made: dissenters were few. ${ }^{80}$ Only the position of the party and the character of the collapse varied, and therefore also the road to the revolutionary situation.

The significance of the peasants' passivity or hostility for the final failure of the revolution was also similar in the two cases. As stated above, in anticolonial revolutions an alliance between the organised revolutionary party and the peasantry has generally been forged well before the opportunity for revolt has presented itself, and this alliance has been essential for victory. In Hungary, power was instead granted to the revolutionaries without their having formed any such alliance; nor had they any real willingness to do so, either before or after their ascent to power. Indeed, the mere fact that power was granted to the revolutionaries made an alliance with the agrarian masses a topic of little moment. In Finland, an alliance did exist, but because a considerable part of the Social Democrats' agrarian following, the crofters, was attracted to the party for economic reasons, when the revolutionary encounter came their support waned. In both Hungary and Finland, the presence of an organised challenger per se was enough to provoke the revolution, but in the longer run the lack of massive agrarian support caused it to be put down or at least greatly contributed to its failure.

In the Balkans, political dependence on the Ottoman Empire made for autonomist nationalism in many cases. Although Romania, Serbia, and Greece achieved independence in the 1800 s and Bulgaria in the early 190os, they remained under the tutelage of the great powers and devoted substantial resources to acquiring ethnically similar or related areas still under Ottoman or Habsburg control. Here, political dependence and the way various regions worked free from it brought about direct economic changes and affected local 
class structures. When the Ottoman export controls were abolished in Romania, for example, the country was rapidly integrated into the Western market. Grain trade with the West soon led to a true 'second serfdom' when the powerful Romanian boyar class reimposed servile obligations on the depressed peasantry. In the other cases the consequences were different because Ottoman rule had not left the lands under indigenous landlords but had replaced the local aristocracies with Turkish overlords. The achievement of political independence was automatically accompanied by economic upheaval as the Turkish landlords abandoned their estates to the peasants who had tilled them. No strong domestic landed class sprang up instantly, and independent Bulgaria, Serbia, and Greece became essentially countries of small peasant proprietors. The peasants' economic backwardness and dependence were soon aggravated by increasing overpopulation, divided holdings, and indebtedness. Politically, however, the peasants could not be disregarded permanently. ${ }^{81}$ In Bulgaria, most notably, the peasant party, the Bulgarian Agrarian National Union, emerged as the main popular opposition force at the beginning of the twentieth century. ${ }^{82}$

Romania and Bulgaria suffered greatly from the war. Their armies disintegrated in its final phase, and in 1918-19 both countries had a large number of unemployed, armed ex-soldiers, many of whom were influenced by the October revolution in Russia. The same is true to a lesser extent of the South Slav regions. Still, the socialists' plans to seize power were inchoate and ineffective. In Romania and Bulgaria the social democratic parties were founded in the 189os, and in Serbia during the next decade, but the industrial working classes were small, having hardly emerged from the peasant base, and political pressure and the low level of education made organisation difficult. The crisis of 1917-18 found the social democrats in the peninsula unable, even unwilling, to organise the peasant masses, and also largely unwilling to follow a revolutionary course. The Bulgarians were the strongest and most successful, the Communist party having been founded in 1919, earlier than elsewhere, but in all cases revolution was not feasible, for the extensive peasant unrest remained divorced from socialist guidance. As was mentioned above, the peasant party emerged from the war as the major organised force in Bulgaria; the comparatively weak upper classes were not in the position to control the situation, and the peasants elevated Alexander Stamboliski, the leader of the Agrarian

\footnotetext{
81 P. Anderson 1974, pp. 390-4; Jelavich and Jelavich 1977, pp. 196-221; Bell 1977, pp. 4, 12-13; Berend and Ránki 1974, pp. 49-52.

82 See Bell 1977 .
} 
National Union, to power. ${ }^{83}$ In Romania the ruling elite had been frightened by the great peasant revolt of 1907 , and in 1917-18 it was prepared to concede to land reform and universal suffrage and thereby assure its own existence and a common front against external threats. Also of considerable significance is the fact that Romania emerged from the war as a victorious power, thus doubling its population and territory. The Romanians became enthused with the creation of a Greater Romania. ${ }^{84}$

The Romanian and Bulgarian experiences demonstrate that governmental incapacity to suppress commitment to alternative claims was not enough to bring about revolutionary situations, even in fully formed polities. As in Hungary, the war was not an encounter that would have brought liberation from an earlier political subordination; instead, it seriously undermined the structures of control in the polities themselves. Apart from governmental incapacity, what was important was the presence or absence of a well-organised challenger. The depressed Romanian peasantry had no such challenger before the war, and none was able to emerge in only a few years. One did take power for a moment in Bulgaria, but in this agrarian country it represented the small proprietors; and however land-hungry they were, the land had already been distributed. They were able to elevate the peasant party to political power for a moment, but the party did not envision a new economic and social order.

In the South Slav regions the foundation of Yugoslavia, with Serbia as its nucleus, took precedence over the other objectives of the major political movements. The class struggle and struggle for national liberation were, for the Serbs, Croats, and Slovenes, 'inseparable': 85 not only had social and national oppression been generally superimposed under Ottoman or Habsburg rule, ${ }^{86}$ but in a number of South Slav regions the religious division reinforced social and national distinctions.

All in all, in East-Central Europe a revolutionary situation arose only in Hungary, the country where the war had destroyed the state apparatus and damaged the social fabric more thoroughly than anywhere else in the region. Although the worker movement was comparatively well organised, it could acquire power only after a total collapse of state authority - in which lay,

83 Bell 1977, pp. 82, 110, 122-53; Rankoff 1977, pp. 466-8, 476-7; Schärf 1967, 195-206.

84 Schärf 1967, pp. 195-9, 218-28; Musat and Zaharia 198o, pp. 44-5o; Roberts 1951, pp. 21-32; Chirot 1976, pp. 151, 155-6.

85 Portal 1971, p. 95.

86 Moritsch 1977, pp. 359-63, 366-71, 377-9, 388, 393-4; Portal 1971, p. 94; Kann 1964, pp. 3056, 243-6. Among the Croats, who had an effective self-administration, a native aristocracy cooperated with Vienna and Budapest. 
moreover, a real risk that the whole country would dissolve. In the two other fully formed polities, boyar-dominated Romania and the 'peasant state' of Bulgaria, ${ }^{87}$ the worker movements were initially weaker and the pressures of war on the polities themselves more limited than in Hungary.

In the cases in which no states or autonomous polities existed and political dependence was deeper, the first concern of the socialists was to create, or re-create, a (national) state rather than to contest for power in an already existing one. But even after the national revolutions were completed (and, of great importance, the political systems at least formally democratised), the worker movements were not willing or able to convert popular movements into social revolutions. Actually, the weakness or moderation of the locally dominant Polish, Czech, Slovak, and South Slav socialist movements in 1917-19 fits in well with nationalism as a liberation movement (see Chapter 5): social and national aspects were closely intertwined until the twentieth century. Small revolutionary groupings could not harness extensive peasant unrest during the brief period of opportunity at the end of the war.

This situation of course contrasts with that in the Baltic Provinces. The Latvians and the Estonians also lacked established autonomous political structures before World War I, but the revolutionary upsurge proved powerful and culminated in a revolutionary situation. The difference seems to stem from the nature of class structure and political dependence in the Baltic Provinces. The comparatively large industrial working class and the labour-repressive methods used in the commercialisation of agriculture played an important part, but they alone were not enough. What is crucial is that there, and only there, a revolutionary party existed that was based primarily on industrial workers and that at the same time was able to forge an alliance with the peasant masses. The locally dominant challengers, the Latvian and Estonian Bolsheviks, had their mother organisation in Russia.

Why was it so easy for the local counterparts of the metropolitan challenger to gain ground in the Baltic Provinces? The answer seems to be, first, that unlike in the Polish, Czech, Slovak, and South Slav cases, the oppressive local upper class was both alien and not of metropolitan nationality. Consequently, the local national movements were not only radical, but they were also willing to develop links with Russian socialist currents. Of no minor importance in this respect was the 'dress rehearsal' of 1905, as Lenin called it, which reinforced contacts with Russian radicals, made evident common interests in the antitsarist struggle, and showed that the landless and poor peasants were ready

87 The phrase was coined at the end of the nineteenth century; see Sugar 1969, p. 53 . 
to dynamite the existing order. Whereas in the Polish and Czech cases it was the metropolitan nationalities - that is, the Russians and Germans - who were opposed, in the Baltic regions it was the locally dominant nationality. Opposition to the metropolis was thus largely social in the sense that it was directed against the autocratic system that ultimately guaranteed the indigenous groups' economic and political subordination. Second, the Poles and Czechs had a recollection of a national polity, whereas the Estonians and Latvians had no such memory.

In short, in the Baltic Provinces grievances were widespread among the industrial workers and the exploited peasant masses, national movements were comparatively recent and defined primarily in terms of opposition to a local alien nationality, and opposition to the autocratic system was shared with radical Russian groups. When the revolutionary movement gathered momentum in the metropole itself in 1905 and 1917 , the local liberation movements did not, at least in the short run, undertake a determined course of action explicitly intended to create separate national states; rather, they simply opposed the existing social and economic order. ${ }^{88}$ The local ethnic and the metropolitan challenges were fused to an extent that was exceptional in Eastern Europe.

\section{Fascism in Eastern Europe}

A revolution occurred in only a few successor states, and even in these it was defeated. But in most cases the upheavals of the war and the disintegration of the empires led to an extension of political democracy comparable to that experienced in Finland in 1906 (Hungary being an exception).

In this sudden gaining of political rights culminated the specific character of the collective action in the formation of the Eastern European latecomer polities (see Chapter 1). In Western Europe, the working classes had gradually organised and mobilised themselves, first in trade unions and then in political parties, and in this way eventually gained membership in the polity. The parliamentarian political system was basically the form that the balance of power assumed in the state when the dominant groups were forced to acknowledge the popular challenge, or the way 'the entrance of the masses onto the historical stage' was institutionalised in these countries. In the East, corresponding systems did not develop in the same way but were instead copied from

88 In the Latvian areas, where internal oppression by the German upper class was accompanied by an external German threat, the Bolshevik takeover actually advanced more rapidly than in the Russian interior. 
the West, achieved when the dominant classes were momentarily weakened but not actually broken by the war. The traditional aristocratic elites, in rough coalition with commercial and manufacturing interests, retained much of their power despite the land reforms, which were carried out merely to forestall new revolutionary upheavals; most of these reforms were limited. ${ }^{89}$

It is in the position of the dominant groups that the basis for Eastern European fascism should first be sought. In all countries of the region, these were to regain much of their political power after a few years. Yet a simple return to the old order was not feasible: not only was it politically inconceivable, but economically the need to mobilise resources was of paramount concern. These countries faced during this period the serious dilemma of all backward countries in the international system, a dilemma that became more serious during the Great Depression, which was far more damaging to Eastern Europe than to Finland. Their economies, both agricultural and industrial, were at the mercy of developments in Western Europe. Economic growth was slow, population increase was faster than in other parts of Europe, and the swelling agrarian proletariat was largely doomed to remain in the countryside. In all the countries of Eastern Europe except Czechoslovakia, the economic structure changed little. ${ }^{90}$ Thorough structural reforms, although needed, were unthinkable in the context of a reactionary coalition. The elites and various middle-class groupings recognised the necessity of modernising, but they tried to bring it about without making fundamental changes in social structures. They tried to solve a problem that was inherently insoluble. ${ }^{91}$

Here, then, is the twin basis for Eastern European fascism: the retention by the traditional elites of a substantial share in power in an era of mass politics, together with extreme economic dependence on Western Europe. ${ }^{92}$ In a number of East-Central European countries, consequently, the authoritarian regimes developed a sort of symbiotic relationship with the native fascist movements, as the only acceptable way in which the masses could be mobilised and economic and social stagnation overcome. To solve the insoluble, they tried to make the reaction 'popular and plebeian' by promulgating, or at least tacitly approving, the fascist parties or wings: these groups could 'remain in the ruling or local majority parties ... they could find a place for themselves in the new parties that the leaders of autocratic dictatorships created to give them-

89 In Romania and the Baltic states the land reforms were exceptionally far-reaching. See, e.g., Simunek 1980, 73-4.

$90 \quad$ See Berend and Ránki 1974, pp. 143-257, 285-97.

91 As Barrington Moore (1966, p. 442) puts it.

92 See Moore 1966, pp. 437-8. 
selves the appearance of popular backing ... or they could expect the dictators to cooperate with them ... or at least look tolerantly at their activities. ${ }^{93}$

Relevant examples are Codreanu's Iron Guard in Romania, Gömbös's Party of National Unity and Szálasi's Arrow Cross in Hungary, and Dmowski's movement in Poland. They were distinguishable from the conservative upper classes but linked to them, and in Depression-stricken Hungary the Party of National Unity even had a fleeting taste of power. Gömbös had tried to mobilise the masses in the 1920s, but the miserable conditions that prevailed in the countryside had frustrated his efforts. He therefore focused on fascistisation from within the prevailing system, notably after the Depression had helped him rise to power. Gömbös had a clear vision of the necessity of popular mobilisation for modernisation, a course that, though alien to the conservatives, was of course far preferable to socialist mobilisation. ${ }^{94}$ Yet the fascist-xenophobic attempts to raise the country from a state of torpor were as temporary and ephemeral in Hungary as elsewhere. In Poland fascist action was much more limited than in Hungary; ${ }^{95}$ and in Romania the authoritarian elites finally put the Iron Guard down, after it had started the march to power in the late 193os. But everywhere, the same tendency - mobilisation of the masses using a native fascist ideology in the attempt to solve problems of uneven modernisation - was discernible.

Finland's differences vis-à-vis Germany and Italy were mentioned above. In these countries, the fascist seizure of power was made possible by the upper classes' need to restore order after the working class had obtained political influence in the wake of the world war. In Finland, no such need existed. Compared with East-Central Europe, too, the basis for fascism seems to have been rather weak in Finland, where there were no strong landed elites or vestiges of labour-repressive agrarian systems and no common international position. The 'nameless horror' 96 among the upper and middle classes, provoked by revolutionary unrest in 1917-18, was similar in Finland and other countries, but this alone did not provoke a rightist dictatorship or provide the foundation for the fascistisation of the political system.

The situation in the new Baltic states was seemingly different from that in East-Central Europe because the German or Polish aristocratic classes were eliminated and the land distributed to the peasants. The difference, however, is more apparent than real. In these countries, too, there was an incongruity between the political system and the social structure, thanks to the powerful

93 Sugar 1971, p. 149.

94 Janos 1982, pp. 244-7, 256-9, 287-9; Simunek 1980, 263-6, 295-302.

95 See Simunek 1980, 236-8, 248, 366-72.

$96 \quad$ Nolte 1968, p. 44. 
but transitory mobilisation of the working class. In its national, social democratic versions, the labour movement participated actively in the constituent assemblies, bringing 'ultra-democratic' constitutions to the new states. ${ }^{97}$ The political systems functioned ineffectively, however, and soon the strong bureaucratic-military-agrarian coalitions began to usurp the powers of the state. Authoritarian systems emerged in Lithuania in 1926-7, and in Estonia and Latvia in 1934 in the wake of the Depression. In all these cases conservative peasant parties took over initially, but later the systems assumed a more-or-less open fascist character - even in Estonia, where the coup had been justified as a move against a fascist-type threat. ${ }^{98}$ The need to reinvigorate the economy and win popular legitimacy was as pressing in the Baltic states as in East-Central Europe. As exporters of agrarian products, in which they almost deliberately specialised (to the detriment of industrial production), the Baltic states were also profoundly dependent on Western Europe. ${ }^{99}$ Both in ideology and in reality, then, the peasant landowners became 'the base of the national edifice,'100 though the peasant parties were largely manipulated by their nonpeasant leaders and were less autonomous than the Agrarian Union in Finland.

Certain affinities exist, however, between conditions in Finland and in the Baltic countries. Svinhufvud was a conservative peasant leader comparable to Päts in Estonia, Ulmanis in Latvia, and Smetona in Lithuania. ${ }^{101}$ The Lapua movement had a pronounced peasantist flavour, and well-to-do peasant parties participated in the Baltic coups. But whereas the Baltic attempts succeeded in fundamentally changing the system and putting their leaders at the head of new dictatorships, in Finland the Lapua movement succeeded only in eliminating the Communists from the political scene and in having Svinhufvud elected president. Indeed, the Finnish attempt to overthrow the existing system was rebuffed by Svinhufvud himself. There is no doubt that the ultrademocratic nature of the Baltic constitutions, as compared with the more conservative Finnish constitution, was one factor contributing to the difference in outcomes, ${ }^{102}$ but in a wider perspective even this is just another indication of differences in the entire pre-world war state-making history and, consequently, in the degree of continuity between the pre- and post-war political systems.

\footnotetext{
97 Schram 1957, p. 63; Hyvämäki 1977, 118-21.

98 On the authoritarian takeovers and subsequent fascistisation, see Schram 1957, pp. 63-7; Remeikis 1977, pp. 252-63; Weiss 1977, pp. 211-19; von Hehn 1977, pp. 232-6.

99 Schram 1957, pp. 55-63, 67-70.

100 Cited in Schram 1957, p. 62.

101 Von Rauch 1967, pp. 146, 152-3.

102 Hyvämäki 1977, p. 135 .
} 
All in all, the most salient feature in the Finnish case is the fact that fascist intrusions remained limited despite the attempt at revolution in 1917-18. Finnish fascism was basically a general bourgeois reaction aimed at the reassertion of the Whites' victory in 1918, which had been partly compromised in 1919 and which seemed threatened by the consolidation of the Soviet Union. As such, it was a culmination of Finnish nationalism - an attempt to regain the long-sought unity that had been lost in the traumatic experience of 1918. The nature of the fascism in Finland resulted from the country's social structure and, notably, from the character of the peasantry. Well organised and mobilised, and with a well-established position in the political system, the Finnish peasantry was totally unlike the Eastern European peasantries, which were frequently exploited by the political elites. Moreover, Finland, again unlike most other successor states, had seen its working class defeated at the very outset of the period. Thus, symbolic adjustments were enough, and increased pressure could be placed on the left without fundamentally altering the prevailing system. 